\title{
Variant Pili Produced by Mutants of the Flac Plasmid
}

\author{
By N. S. WILLETTS, ${ }^{1 *}$ P. M. MOORE ${ }^{2}$ AND W. PARANCHYCH ${ }^{2}$ \\ 1 Department of Molecular Biology, University of Edinburgh, \\ Edinburgh EH9 3JR, Scotland \\ 2 Department of Biochemistry, University of Alberta, Edmonton, Canada
}

(Received 13 June 1979; revised 24 September 1979)

\begin{abstract}
Transfer-proficient Flac mutants with reduced abilities to plate various F-specific phages were isolated, either by selection after mutagenesis, or as revertants of Flac traA mutants. In many of the mutants pilus-related properties were altered, including physical adsorption of R17 phage, the number of pili per cell and the outgrowth/retraction equilibrium. Complementation studies showed that the mutations were in $\operatorname{traA}$, suggesting that specific alterations in the amino-acid sequence of the pilin subunit protein were responsible for the altered pilus properties. Complementation between the Flac traA mutants and the derepressed plasmid R100-1 restored phage sensitivity in some cases, suggesting that the incorporation of both mutant and R100-1 subunits into the pilus structure may result in conformational changes which increase the capacity of the pilus to interact with phages.
\end{abstract}

\section{INTRODUCTION}

The pilus that is determined by the $E$. coli $\mathrm{K} 12$ sex factor $\mathrm{F}$ is an extracellular filamentous structure about $8 \mathrm{~nm}$ in diameter and 1 to $2 \mu \mathrm{m}$ long (Folkhard et al., 1979). One or two pili per cell are usually observed. The pilus is essential for conjugation, being the means whereby the donor and recipient cells establish contact (Achtman \& Skurray, 1977); it may also be involved in triggering conjugal plasmid DNA metabolism (Kingsman \& Willetts, 1978) and perhaps in the DNA transfer process per se (Brinton, 1971). The pilus also serves as the site of adsorption of 'F-specific' RNA and single-stranded DNA phages: RNA phages adsorb along the sides of the pilus (Crawford \& Gesteland, 1964; Paranchych, 1975) and the filamentous DNA phages at the tip (Caro \& Schnös, 1966). The pilus's function in both conjugation (Ou \& Anderson, 1970) and F-specific phage infection (Jacobson, 1972; Marvin \& Hohn, 1969) may depend upon its ability to retract into the donor cell. During this process, which also occurs when cells are treated with arsenate (O’Callaghan et al., 1973) or cyanide (Novotny \& Fives-Taylor, 1974), pilin subunits dissociated at the base of the pilus may redissolve in the cell membrane.

The $\mathrm{F}$ pilus has been purified and analysed biochemically. It consists of a single subunit protein, pilin, which has a molecular weight of 10800 to 11800 and carries two phosphate groups and one glucose residue per molecule (Brinton, 1971; Date et al., 1977; Helmuth \& Achtman, 1978). Furthermore, the genetics of the conjugation process have been elucidated, in particular identifying 12 transfer (tra) genes falling in a single operon that are required for pilus formation (Helmuth \& Achtman, 1975; Miki et al., 1978). Of these genes, traA determines the pilin precursor protein (Minkley et al., 1976), while the others are presumed to determine a biochemical pathway for its conversion to the extracellular pilus.

Most F-specific phage-resistant F mutants so far described are transfer-deficient and do not form an extracellular pilus (Achtman et al., 1971, 1972; Ohtsubo et al., 1970). However, 
Table 1. Bacterial strains

\begin{tabular}{lcccccccc}
$\begin{array}{c}\text { Strain } \\
\text { no. }\end{array}$ & His & Trp & Lys & Lac & T6 & Str & Spc & Other \\
ED24 & + & + & + & - & R & S & R & \\
JC3272 & - & - & - & - & R & R & S & Fla $^{-}$ \\
ED2601* & - & - & - & - & R & R & S & SuI $^{+}$ \\
JC6255 & + & - & + & - & S & S & S & S \\
JC6256 & + & - & + & - & S & S & S & \\
JC5462 & - & + & + & - & R & R & R & \\
\multicolumn{7}{c}{ * An ethyl methanesulphonate-induced Fla- mutant of JC3272. } &
\end{tabular}

a few F mutants partially or completely resistant to one or more F-specific phages, but still largely transfer-proficient, have been obtained (Tomoeda et al., 1972; R. M. Weppelman, K. Ippen-Ihler \& C. C. Brinton, unpublished work, reported by Paranchych, 1975). Similar mutants of the F-like plasmid R192-7 were isolated by Orosz \& Wootton (1977). However, these studies investigated the phenotype but not the genotype of the mutants (except for the unpublished Weppelman mutants; see Discussion). Therefore, in an attempt to delineate further the dual role of the pilus in conjugation and F-specific phage infection, we have isolated a series of Flac mutants that are deficient mainly in the latter function and determined both their pilus-related and genetic properties.

\section{METHODS}

Bacterial strains and plasmids. The strains used as hosts for the plasmids in this study are described in Table 1. The Flac elements JCFL0 (wild-type), JCFL1 (Flac traAl amber), JCFL18 (Flac traE18 amber), JCFL25 (Flac traA25 amber), JCFL32 (Flac traA32 opal), JCFL44 (Flac traA44 missense) and JCFL107 (Flac traA107 frameshift) were described by Achtman et al. (1971, 1972) and Willetts \& Achtman (1972). JCFL 32 was originally considered to carry a traL mutation polar upon traA (Willetts, 1973), but it now seems more likely that it carries a $\operatorname{traA}$ mutation polar upon $\operatorname{traL}$, as is discussed in the present paper.

Media. These have been described (Finnegan \& Willetts, 1971).

Mutagenesis. Treatment of cells with ethyl methanesulphonate (EMS) was described by Willetts (1973). Treatment with $N$-methyl- $N^{\prime}$-nitro- $N$-nitrosoguanidine (NTG) was similar, except that the cells were resuspended in $5 \mathrm{ml} 0.1 \mathrm{M}$-citrate buffer $\mathrm{pH} 5.5$ and NTG was added to a final concentration of $100 \mu \mathrm{g} \mathrm{ml}^{-1}$. For mutagenesis with ICR191A (ICR), $0.01 \mathrm{ml}$ ICR $\left(1 \mathrm{mg} \mathrm{ml}^{-1}\right.$ in water) was mixed with $1 \mathrm{ml}$ of a $10^{-3}$ dilution of an overnight broth culture in glucose-Casamino acids minimal medium and further incubated overnight at $37^{\circ} \mathrm{C}$.

Mating conditions. These have been described (Gasson \& Willetts, 1977).

F-specific phage plating. The efficiencies of plating of the F-specific phages $\mathrm{f} 1, \mathrm{f} 2, \mathrm{R} 17$ and $\mathrm{M} 12$ were measured using the procedure of Achtman et al. (1971).

${ }^{32}$ P-labelled R17 adsorption. Purified, ${ }^{32} \mathrm{P}$-labelled R17 phages were added in large excess $\left(10^{4}\right.$ physical particles cell $\left.{ }^{-1}\right)$ to $2 \mathrm{ml}$ of a chilled exponential phase culture $\left(1 \times 10^{8}\right.$ cells $\left.\mathrm{ml}^{-1}\right)$ of the appropriate $E$. coli strain in L-broth. After allowing the phage to adsorb at $4{ }^{\circ} \mathrm{C}$ for $40 \mathrm{~min}$ with occasional gentle mixing, the cells were pelleted by centrifugation for $10 \mathrm{~min}$ at $10000 \mathrm{~g}$. The pellet was resuspended in $0.2 \mathrm{ml} \mathrm{M} 9$ buffer, then $0.1 \mathrm{ml}$ of the resuspension was absorbed on to a Whatman 3MM filter paper disc $(2.5 \mathrm{~cm} \mathrm{diam}$.). The filter discs were dried for $60 \mathrm{~min}$ at $60{ }^{\circ} \mathrm{C}$, then assayed for radioactivity by counting in $5 \mathrm{ml}$ toluene-based scintillation fluid; $\mathbf{F}^{-}$cultures were used as controls to correct for non-specific trapping of phages in the cell pellet.

Electron microscopy. For electron microscopic examination of piliated cells, a drop of cell suspension $\left(2 \times 10^{8}\right.$ to $5 \times 10^{8}$ cells $\left.\mathrm{ml}^{-1}\right)$ was placed on a carbon-coated support grid, washed two or three times with distilled water, then stained with $1 \%(\mathrm{w} / \mathrm{v})$ phosphotungstic acid, $\mathrm{pH} 7$, for $20 \mathrm{~s}$. Pili were counted either by direct observation in the electron microscope or on electron micrographs. Care was taken to examine only those cells which were uniformly stained and clearly outlined. No attempt was made to correct for pili which did not protrude beyond the edge of a cell. The accuracy of pilus counts was such that the percentage error was always less than $\pm 10 \%$.

Pilus retraction in the presence of cyanide. Sodium cyanide $(0.01 \mathrm{~m}$ final concentration) was added to early-exponential phase cells $\left(2 \times 10^{8}\right.$ cells $\left.\mathrm{ml}^{-1}\right)$ in L-broth. The culture was incubated with shaking at 
$37^{\circ} \mathrm{C}$. At 5 and $20 \mathrm{~min}$ after cyanide addition, samples were removed from the culture, quickly chilled to $4{ }^{\circ} \mathrm{C}$, then prepared for electron microscopic examination as described above.

Titre-increase complementation experiments. A sample $(0.1 \mathrm{ml})$ of an exponential phase culture of a derivative of JC6255 carrying a $\operatorname{Tra}^{+}$F-specific phage-resistant mutant was mixed with $0.1 \mathrm{ml}$ of a $1: 10$ dilution in broth of a shaken overnight $\left(\mathrm{F}^{-}\right.$phenocopy) culture of the recipient strain, and mated for 40 min at $37^{\circ} \mathrm{C}$. The recipient strain was JC3272 or a derivative carrying JCFL1 (Flac tra A1) or JCFL18 (Flac traE18). A u.v.-killed T6 phage lysate $\left(0.2 \mathrm{ml} ; 10^{11} \mathrm{ml}^{-1}\right)$ was added, and incubation was continued for $20 \mathrm{~min}$ to kill the $\mathrm{T} 6^{\mathrm{B}} \mathrm{JC} 6255$ donor strain. Then $0.5 \mathrm{ml}$ broth was added, and the culture was incubated for $40 \mathrm{~min}$ to allow expression of the tra genes. Finally, $0.1 \mathrm{ml} \mathrm{R} 17\left(10^{5}\right.$ plaque-forming units $\mathrm{ml}^{-1}$ in Lbroth containing $0.05 \mathrm{M}-\mathrm{CaCl}_{2}$ for adsorption) was added. Incubation was continued for a further $2 \mathrm{~h}$ to allow growth and titre increase of the phage, after which the culture was treated with chloroform and its R17 titre was measured.

Pilot experiments had shown that infection with a low multiplicity of R17 gave the highest titre increases, and that a $2 \mathrm{~h}$ period for phage increase gave the biggest difference between negative and positive controls. Also, since many of the Tra ${ }^{+}$F-specific phage-resistant mutants were leaky, it was best to use these as donors rather than recipients since the donor cells were lysed with T6 prior to addition of R17. However, in one case (EDFL32), where the donor ability of the mutant plasmid was low and it was very resistant to male-specific phages, the experiment was reversed: JCFL1 and JCFL18 were present in the SuI ${ }^{+}$JC6255 $^{2}$ donor strains, and EDFL32 in the JC3272 recipient strain.

\section{RESULTS}

\section{Isolation of mutants partially resistant to $\mathrm{F}$-specific phages}

Single colonies of JC6256 (JCFL0) ${ }^{+}$were picked and used to inoculate cultures that were mutagenized in early-exponential phase with either EMS or NTG as described in Methods. The mutagenized cultures were diluted 1:20 into L-broth and incubated overnight to allow expression of induced mutations, and then further diluted 1:20 and infected with either $\mathrm{f} 1, \mathrm{R} 17$ or $\mathrm{Q} \beta$ phage (multiplicity of infection $=50$ ). After incubating the cultures for approximately $60 \mathrm{~min}$, at which time the density was about $2 \times 10^{8} \mathrm{cells} \mathrm{ml}^{-1}$, an equal volume of an early-exponential phase $\left(2 \times 10^{8}\right.$ cells $\left.\mathrm{ml}^{-1}\right)$ culture of $\mathrm{F}^{-}$cells (ED2601) was added. The mixtures were incubated for an additional $30 \mathrm{~min}$, then diluted appropriately and plated on minimal plates to select for ED2601 cells which had acquired the Flac plasmid. The donor abilities of these $\mathrm{Lac}^{+}$clones were tested by inoculating patches of each on to a master plate of nutrient agar, allowing these patches to grow for 6 to $8 \mathrm{~h}$, and then replica-plating on to a lawn of the recipient strain ED24 which had been spread on minimal medium selective for $\mathrm{Lac}^{+}\left[\mathrm{His}^{+} \mathrm{Trp}^{+} \mathrm{Lys}^{+} \mathrm{Spc}^{\mathrm{R}}\right]$ progeny. Those clones which showed high donor abilities were purified and further tested for their sensitivity to various F-specific phages. The phage resistance patterns and donor abilities of six mutants isolated in this manner are shown in Table 2.

It is evident that a wide variety of pilus phenotypes could be isolated by selecting for $\mathrm{Tra}^{+}$F-specific phage-resistant cells. As a general rule (WPFL51 was an exception), there was a reasonable correlation between donor ability and sensitivity to the filamentous DNA phage $\mathrm{fl}$. Since both bacterial conjugation and $\mathrm{fl}$ adsorption involve the pilus tip, this correlation was not surprising. Similarly, sensitivities to the two RNA phages, which attach to the side of the pilus, were usually reduced to similar extents. However, two mutants, WPFL44 and WPFL51, which appeared to be completely resistant to the RNA phage $\mathrm{Q} \beta$, retained a significant ability for promoting $\mathrm{R} 17$ phage infection. This is perhaps indicative of the highly specific interaction between pilus protein and the A-protein of RNA phages (Paranchych, 1975).

A second method used for the isolation of pilus mutants was to screen mutagen-induced $\mathrm{Tra}^{+}$revertants of traA point mutants for those with unusual F-specific phage plating characteristics. For this, the assumption was made that traA determines the F-pilin subunit, as had been indicated by the experiments of Willetts (1971) and was later substantiated by 
Table 2. Partially phage-resistant mutants of JCFL0

\begin{tabular}{lcccccc} 
Plasmid & Mutagen & $\begin{array}{c}\text { Phage used } \\
\text { for } \\
\text { selection }\end{array}$ & $\begin{array}{c}\text { Donor } \\
\text { ability* } \\
(\%)\end{array}$ & \multicolumn{2}{c}{ Efficiency of plating $\dagger$} \\
EDFL4 & EMS & - & 30 & $<1$ & $\mathrm{R} 17$ & $\mathrm{Q} \beta$ \\
EDFL32 & EMS & - & $0 \cdot 5$ & $<0 \cdot 5$ & $<0 \cdot 2$ & $<0 \cdot 5$ \\
WPFL43 & EMS & $\mathrm{Q} \beta$ & 60 & 71 & 6 & $<0 \cdot 5$ \\
WPFL44 & NTG & $\mathrm{Q} \beta$ & 117 & 79 & 6 & $<10^{-4}$ \\
WPFL45 & NTG & $\mathrm{Q} \beta$ & 78 & 85 & 1 & $<10^{-4}$ \\
WPFL46 & NTG & $\mathrm{f} 1$ & 5 & $<10^{-4}$ & $<10^{-4}$ & $<10^{-4}$ \\
WPFL47 & NTG & $\mathrm{R} 17$ & 74 & 74 & $<10^{-4}$ & $0 \cdot 2$ \\
WPFL51 & NTG & $\mathrm{Q} \beta$ & 55 & 1 & 20 & $<10^{-4}$
\end{tabular}

* Measured using a derivative of ED2601 as donor and ED24 as recipient, and expressed as the number of transconjugants per 100 donor cells.

$\dagger$ Measured using a derivative of ED2601, and expressed as a percentage of the number of plaques obtained using the (JCFLO) ${ }^{+}$derivative of ED2601.

$\ddagger$ Isolated as a $\mathrm{Tra}^{+}$revertant from the nonsense (UGA) mutant traA32.

$\S$ Isolated as a $\mathrm{Tra}^{+}$revertant from the nonsense (UAG) mutant traA25.

Table 3. Complementation by measurement of $\mathrm{R} 17$ titre-increase

\begin{tabular}{lrrr} 
& \multicolumn{3}{c}{ Plasmid in recipient strain* } \\
Plasmid in & & & \\
donor strain & None & JCFL1 & JCFL18 \\
None & & 5 & 6 \\
JCFL0 & 18000 & 3100 & 34000 \\
JCFL1 & 65 & 135 & 10500 \\
EDFL4 & 440 & 62 & 1840 \\
EDFL32† & 69 & 780 & 22000 \\
WPFL43 & 400 & 200 & 2300 \\
WPFL44 & 300 & 35 & 39000 \\
WPFL45 & 130 & 33 & 14000 \\
WPFL46 & 6 & 19 & 1300 \\
WPFL47 & 8 & 16 & 48000 \\
WPFL51 & 875 & 15 & 3000
\end{tabular}

* Numbers represent the ratio of yield to inoculum.

$\dagger$ EDFL32 was present in the recipient cells for construction of the transient heterozygotes (see Methods). $\ddagger$ Phage $\mathrm{Q} \beta$ was used in place of $\mathrm{R} 17$.

Minkley et al. (1976). Pseudo-wild-type revertants carrying two mutations in traA might possibly restore the transfer function but not the ability to plate F-specific phages normally.

Accordingly, derivatives of JC3272 carrying the various Flac traA elements were mutagenized as described in Methods, and Tra+ revertants were selected in matings with ED24. Five independent $\mathrm{Tra}^{+}$revertants isolated from each of JCFL1, JCFL44 and JCFL107 had all simultaneously regained high levels of plating of F-specific phages and were not further characterized. However, one out of five Tra ${ }^{+}$revertants from JCFL25 (Flac traA25), and three out of four from JCFL32 (Flac traA32) showed reduced efficiencies of plating. Results for the JCFL25 revertant (EDFL32) and one of the JCFL32 revertants (EDFL4) which was originally described by Willetts (1973) are included in Table 2.

\section{Complementation analysis}

Attempts were made to discover which, if any, tra gene carried the mutations responsible for the $\mathrm{Tra}^{+} \mathrm{F}$-specific phage-resistant phenotype. The most likely candidate was traA, since Minkley et al. (1976) have shown that this is the structural gene for the pilin subunit protein. Complementation with traA and, for comparison, $\operatorname{traE}$, was therefore tested. 
For the complementation experiments, transient heterozygotes were constructed carrying both a Tra ${ }^{+}$F-specific phage-resistant mutant and either JCFL1 (Flac traA1) or JCFL18 (Flac traE18), as described in Methods. If complementation occurs the cells should produce pili, rendering them F-specific phage-sensitive. This was tested by adding $\mathrm{R} 17$ phage and measuring any increase in titre after $2 \mathrm{~h}$ incubation.

Control experiments using heterozygotes carrying wild-type JCFLO or both JCFL1 and JCFL18 showed that titre increases of several thousand-fold were to be expected where complementation occurred (Table 3). In contrast, control experiments using JCFL1 as donor, where no complementation was expected, gave titre increases of about a hundredfold: this relatively small increase is probably due to survival of some $\mathrm{Tra}^{+} \mathrm{F}$-specific phage-sensitive JC6255 cells after the T6 treatment.

For some of the $\mathrm{Tra}^{+}$F-specific phage-resistant mutants, the results of the complementation test were clear: low titre increases were found when either no other plasmid or JCFLl was present in the transient heterozygote cells, and high titre increases when JCFL18 was present (Table 3). This was the case for EDFL32, WPFL44, WPFL45 and WPFL47, and proved that the mutations carried by these plasmids must lie in traA. For the mutants EDFL4, WPFL43, WPFL46 (which is a poor donor) and WPFL51, complementation of JCFL18 was not at such a high level (about $15 \%$ ) but again the absence of any complementation of JCFL1 indicates that these plasmids also carry traA mutations.

\section{Pilus-related properties of the mutants}

The foregoing studies show that it was possible to generate a variety of $\mathrm{Tra}^{+}$pilus mutants defective or partially defective in their abilities to promote infection by one or more F-specific phages. As shown by the complementation studies probably all such mutations were within the structural gene for pilin (traA), presumably as point mutations giving rise to single amino-acid substitutions. These missense mutations may have altered the affinity of the pilus for a given bacteriophage, giving rise to the various phenotypes shown in Table 2. Alternative explanations for some of these phenotypes, however, could derive from reduced levels of piliation or of phage nucleic acid penetration, the latter perhaps resulting from a reduced capability of the pilus to undergo retraction.

The mutants were therefore examined for several pilus-related properties. The level of piliation was determined by direct electron microscopic examination of cells, and the maximum amount of R17 phage that could adsorb to each cell was found using radioactively labelled phage particles. The putative ability of cells to undergo pilus retraction was tested by determining the level of piliation before and after treatment with sodium cyanide. The latter metabolic poison has been shown previously (Novotny \& Fives-Taylor, 1974) to cause the disappearance of pili from cell surfaces. The results of these experiments are summarized in Table 4.

Cells containing EDFL4, EDFL32 and WPFL46 had low pili levels which may be responsible for their inefficiency as donors and at promoting phage growth. However, the efficiency of EDFL4-carrying cells at adsorbing R17 was very low while that of WPFL46carrying cells was normal and their resistances to $\mathrm{R} 17$ may therefore be due to poor adsorption and poor RNA penetration, respectively. WPFL51-containing cells were relatively efficient at donor function and at promoting $\mathrm{R} 17$ adsorption and infection, but they were poor at promoting infection by phages $\mathrm{f} 1$ and $\mathrm{Q} \beta$. Since $\mathrm{f} 1$ and $\mathrm{Q} \beta$ attach poorly even to wild-type cells, it was not possible to determine whether the resistance to $\mathrm{f} 1$ and $\mathrm{Q} \beta$ was due to poor attachment or to an inability to mediate nucleic acid penetration. All these strains, except that containing EDFL32 which had very few pili in the first place, showed a significant decrease in the level of piliation when treated with cyanide, demonstrating that the pili are all still able to retract.

Cells containing WPFL43, WPFL44, WPFL45 and WPFL47 all had normal or higher 
Table 4. Pilus-related properties of mutant plasmids

\begin{tabular}{lrcccc} 
R17 & R17 & \multicolumn{3}{c}{ No. of pili per 100 cells } \\
Plasmid & $\begin{array}{c}\text { Before CN- } \\
\text { treatment }\end{array}$ & $\overbrace{5 \text { min }}^{\text {After } \mathrm{CN}^{-} \text {treatment }}$ & 20 min \\
JCFL0 & 100 & 100 & 143 & 25 & 14 \\
EDFL4 & 0 & 1 & 21 & 9 & 6 \\
EDFL32 & 0 & 0 & $<1$ & $<1$ & $<1$ \\
WPFL43 & 6 & 589 & 719 & 98 & 99 \\
WPFL44 & 6 & 272 & 325 & 81 & 121 \\
WPFL45 & 1 & 209 & 228 & 17 & 26 \\
WPFL46 & 0 & 72 & 14 & 4 & 6 \\
WPFL47 & 0 & 57 & 98 & 36 & 7 \\
WPFL51 & 20 & 82 & 145 & $<1$ & $<1$
\end{tabular}

* All values have been normalized to the control (JCFL0), which adsorbed approximately 800 R 17 particles per cell.

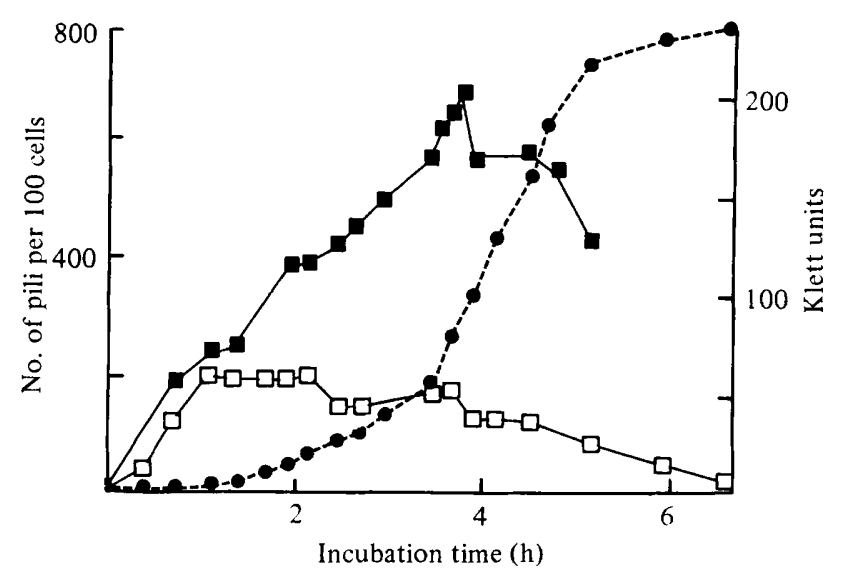

Fig. 1. Effect of cell growth on the level of piliation of $E$. coli carrying the wild-type Flac plasmid JCFL0 $(\square)$ and the mutant plasmid WPFL43 ( $\square$ ). Each point represents the total number of attached pili per 100 cells, as seen by electron microscopy. Cell density (O) is shown in Klett units.

than normal levels of pili. These strains adsorbed R17 phage efficiently but were very poor at promoting phage growth, presumably because they were unable to allow phage RNA penetration. WPFL43, WPFL44 and WPFL45 were of particular interest since they produced higher than normal levels of pili as demonstrated both by direct pili counts and by R17 adsorption. WPFL43-containing cells (the most highly piliated of the three) were therefore subjected to further examination.

Figure 1 shows the levels of piliation of strains carrying JCFL0 or WPFL43 plasmids at various stages of the growth cycle. The level of piliation of JCFL0-containing cells reached about two pili per cell at very early-exponential phase, then declined gradually throughout the remainder of the growth cycle. At mid-exponential phase, the pilus density was only about one per cell. In the mutant culture, on the other hand, the pilus level continued to increase throughout the growth cycle until late-exponential phase, at which time there was an average of about 6 to 7 pili per cell.

Further insights into the multi-piliated nature of WPFL43-containing cells were obtained by examining the pilus behaviour of these and JCFLO-containing cells at $20^{\circ} \mathrm{C}$ and $37{ }^{\circ} \mathrm{C}$. The frequency of JCFLO pili remained relatively constant at $37^{\circ} \mathrm{C}$, but declined markedly 


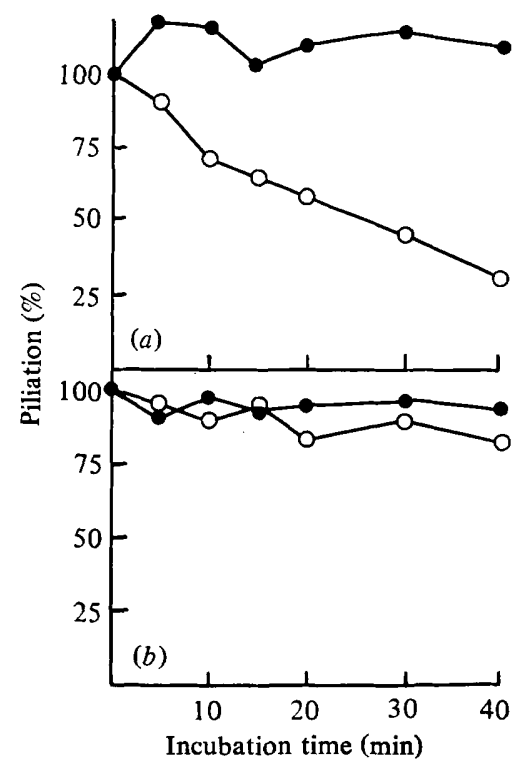

Fig. 2. Effect of different temperatures $\left(O, 20^{\circ} \mathrm{C} ; O, 37^{\circ} \mathrm{C}\right)$ on the level of piliation of $E$. coli ED2601 carrying the wild-type Flac plasmid JCFL0 $(a)$ and the mutant plasmid WPFL43 (b). Each point represents the total number of attached pili per 100 cells, as seen by electron microscopy, expressed as a percentage of the corresponding number at time 0 .

at $20{ }^{\circ} \mathrm{C}$ (Fig. $2 a$ ). In the case of WPFL43 pili (Fig. $2 b$ ), there was no apparent loss of pili from the cell surface upon cooling the culture to $20^{\circ} \mathrm{C}$. One interpretation of this observation is that the outgrowth of JCFL0 pili is preferentially inhibited at $20^{\circ} \mathrm{C}$, while the WPFL43 mutation allows pilus outgrowth at $20^{\circ} \mathrm{C}$ to continue at the same rate as retraction.

Novotny \& Fives-Taylor (1974) have proposed that pili are constantly being assembled in the membrane to give rise to pilus outgrowth, and then being depolymerized in the membrane to give rise to pilus retraction. There are presumably many potential sites of pilus outgrowth on the cell surface, but the equilibrium of outgrowth and retraction is such that only 1 to 2 pili per cell are present at any given instant. If we infer from the results shown in Fig. 2 that the rate of outgrowth of WPFL43 pili is greater than that of JCFL0 pili (at $37^{\circ} \mathrm{C}$ as well as $20^{\circ} \mathrm{C}$ ), the resulting shift in equilibrium should give rise to the observed multi-piliated phenotype. Such a shift in equilibrium could also arise from a defect in the ability of pili to retract. However, the NaCN experiment shown in Table 4 indicates that WPFL43 pili are as efficient at retraction as are JCFL0 pili.

\section{Complementation between $\mathrm{R} 100-1$ and $\mathrm{Tra}^{+}$F-specific phage-resistant Flac mutants}

It was shown previously (Willetts, 1971) that R100-1, when present in the same cell as Flac traA25, complemented this with respect to transfer of the Flac but not for restoration of the high efficiencies of plating of F-specific phages found on strains carrying wild-type Flac. The latter result was as expected, since strains carrying R100-1 alone plate F-specific phages very poorly, probably because the R100-1 pilin subunit allows only poor phage adsorption. Similar findings have now been made for all the available transfer-deficient Flac traA mutants, including the one probable missense mutant JCFL44 (Table 5). However, it seemed possible that 'interallelic' complementation might occur between the F-specific phage-resistant $\mathrm{Tra}^{+}$mutants that still produce pili (Table 4), and R100-1, to 
Table 5. Effect of inter-allelic complementation on the efficiency of plating of F-specific phages

\begin{tabular}{|c|c|c|c|}
\hline \multirow[b]{2}{*}{ Plasmids } & \multicolumn{3}{|c|}{ Efficiency of plating* } \\
\hline & fl & R17 & $\mathrm{Q} \beta$ \\
\hline R100-1, JCFL0 & 39 & 70 & 60 \\
\hline R100-1, JCFL44† & 1 & 0 & 0 \\
\hline R100-1, EDFL4 & 26 & 22 & 2 \\
\hline R100-1, WPFL46 & 28 & 31 & 2 \\
\hline R100-1, WPFL51 & 62 & 37 & 21 \\
\hline R 100-1, WPFL44 & NT & 9 & 0 \\
\hline R100-1, WPFL45 & NT & 32 & 1 \\
\hline R100-1, WPFL47 & NT & 23 & 0 \\
\hline JCFL25 in SuI ${ }^{+}$ & $<1$ & $<1$ & $<1$ \\
\hline $\mathrm{JCFL}^{25}$ in SuIII ${ }^{+}$ & 5 & 35 & $<1$ \\
\hline $\mathrm{R} 100-1, \mathrm{JCFL} 25$ in $\mathrm{SuI}^{+}$ & 7 & 17 & $<1$ \\
\hline R100-1, JCFL25 in SulII ${ }^{+}$ & 8 & 121 & 1 \\
\hline
\end{tabular}

NT, Not tested.

* The host strain was JC3272 or ED2601, except for the suppressor strains $\mathrm{SuI}^{+}$(JC6255) and SuIII ${ }^{+}$ (JC6650). Results are expressed as a percentage of the number of plaques obtained using the appropriate (JCFLO) ${ }^{+}$derivative.

† Similar results were obtained using JCFL1 (traA1), JCFL25 (traA25), JCFL32 (traA32) and JCFL107 (traA107).

restore a high efficiency of plating of one or more of the F-specific phages on strains carrying both plasmids.

Those F-specific phage-resistant mutants were chosen which gave a very low efficiency of plating of one or more F-specific phages, and yet still produced pili. Their R100-1 derivatives were made, and the efficiencies of plating of the appropriate F-specific phages were measured (Table 5). On comparison with the results in Table 2 for the efficiencies of plating on strains carrying the Flac mutants alone, it can be seen that in some cases the simultaneous presence of R100-1 gave a substantial increase in efficiency. The pattern of which phages were plated with significantly increased efficiencies was different for different Flac mutants: WPFL44 gave no increase, WPFL45 and WPFL47 gave increases for R17 but not $\mathrm{Q} \beta$, WPFL51 gave an increase for $\mathrm{f} 1$ and $\mathrm{Q} \beta$ but perhaps not R17, and EDFL4 and WPFL46 gave increases for $\mathrm{f} 1$ and $\mathrm{R} 17$ but not $\mathrm{Q} \beta$. These variations may reflect the differences in the precise natures and positions of the traA pilin mutations carried by these plasmids.

This complementation had been observed previously for EDFL4 (Willetts, 1973), and being unexpected at that time, was the reason why JCFL32 (of which EDFL4 is a Tra ${ }^{+}$ revertant) was originally thought to carry a traL mutation polar on $\operatorname{traA}$, rather than a $\operatorname{traA}$ mutation polar on traL, as now seems to be the case.

Flac traA25 is poorly suppressed by $\mathrm{SuI}^{+}$and $\mathrm{SuIII}^{+}$strains for both transfer (Achtman et al., 1972) and plating of F-specific phages (Table 5). Although it was not known how many pili were produced by the cell under these conditions, complementation to F-specific phage sensitivity by $\mathrm{R} 100-1$ in $\mathrm{Su}^{+}$host strains was measured in a way similar to that described above. The results (Table 5) showed a substantial restoration of the ability to plate R17 (and also M12, results not given), some restoration for $\mathrm{f} 1$, but none for $\mathrm{Q} \beta$. This situation therefore resembles that for the F-specific phage-resistant $\mathrm{Tra}^{+}$mutants.

One explanation for this complementation phenomenon is that although the Flac mutant and R100-1 pilin subunits both separately form pili that are poor at adsorbing F-specific phages, interaction of the two types of subunit in a mixed pilus (Lawn et al., 1971) gives conformational changes resulting in a pilus capable of the increased adsorption and plating efficiency observed. 


\section{DISCUSSION}

These results confirm that it is possible to make Flac mutants that have altered pili, but are still transfer-proficient. Although these mutants were initially selected as showing a reduced sensitivity to one of the F-specific phages, pleiotropic mutations with effects on other pilus properties were usually observed. These included increased resistance towards the other F-specific phages, somewhat reduced donor abilities, alterations in the number of pili per cell, and possible defects in outgrowth or retraction ability.

The most common type of mutant pili, made by WPFL43, 44, 45 and 47 , gave almost complete sensitivity to $\mathrm{f} 1$, but total or almost total resistance to both $\mathrm{R} 17$ and $\mathrm{Q} \beta$. Similar mutants have been isolated by R. Weppelman, D. Popkin, K. Ippen-Ihler and C. C. Brinton (personal communication) and two were shown to carry mutations in traA by complementation tests similar to those described here. All our mutants adsorbed R17 phage well, and the defect in R17 infection is presumably due to a failure of the ejection or penetration stages: the experiments necessary to distinguish between these possibilities have not yet been carried out. Of these four mutants, WPFL43, 44 and 45 made two- to fivefold more pili than normal, and both cyanide treatment and temperature-shift experiments suggested that this resulted from defects in the abilities of these pili to retract or from an increase in their rate of outgrowth. The pili gave near-normal levels of conjugation and $\mathrm{f} 1$ sensitivity, so that the altered equilibrium in outgrowth/retraction did not affect the performance of these two functions.

Other mutants showed other combinations of altered pilus properties. Cells carrying the weakly Tra ${ }^{+}$mutant WPFL46, for example, were resistant to $\mathrm{f} 1, \mathrm{R} 17$ and $\mathrm{Q} \beta$, but gave almost normal R17 adsorption although they were apparently piliated to only about $10^{\circ} \%$ of normal. One possible explanation for this anomalous result may be that the cells carried numerous short pili which were capable of attaching R17 phage but which were not easily seen with the electron microscope. Cells carrying WPFL51 were resistant to $\mathrm{Q} \beta$ and $\mathrm{fl}$, and partially resistant to $\mathrm{R} 17$ : piliation and $\mathrm{R} 17$ adsorption were similar to normal. Cells carrying EDFL4 retained about one-quarter of the normal transfer and piliation levels, but were resistant to all three classes of F-specific phages and adsorbed $\mathrm{R} 17$ very poorly.

All these altered phenotypes seemed to result from mutations in traA. We therefore suggest that specific alterations in the amino-acid sequence of the pilin precursor protein, encoded by $\operatorname{traA}$, give rise to particular combinations of altered pilus properties. If recent claims that traA is not the pilin subunit protein gene (Achtman et al., 1979) are substantiated, this conclusion will need to be modified appropriately.

Although it is not yet known how pilin subunits are assembled into the pilus, the complementation for increased plating of F-specific phages observed between R 100-1 and some of the $\mathrm{Tra}^{+} \mathrm{F}$-specific phage-resistant mutants suggests that this is accompanied by a conformational change in the pilin structure. This idea is also supported by the observation that three of the phage-resistant mutants reported in this paper had acquired a multi-piliated phenotype: multi-piliation is believed to arise from an increased rate of pilus outgrowth, in which case a conformational change in subunit structure provides the simplest explanation.

Future studies on these altered pili will include peptide mapping and amino-acid sequencing studies to determine the nature of the changes in the primary structure, as well as circular dichroism and X-ray fibre diffraction studies to detect possible changes in secondary structure and subunit-subunit interactions.

We are grateful to John Maule for his excellent technical assistance, and to Dr Karin Ippen-Ihler for communicating results prior to publication. This work was supported in part by the Medical Research Council of Canada. 


\section{REFERENCES}

Achtman, M. \& Skurray, E. (1977). A redefinition of the mating phenomenon in bacteria. In Microbial Interactions, vol. 3, pp. 232-279. Edited by J. L. Reissig. London: Chapman and Hall.

Achtman, M., Willetts, N. S. \& Clark, A. J. (1971). Beginning a genetic analysis of conjugational transfer determined by the $\mathrm{F}$ factor in $E$. coli by isolation and characterisation of transferdeficient mutants. Journal of Bacteriology 106, 529-538.

Achtman, M., Willetts, N. S. \& Clark, A. J. (1972). A conjugational complementation analysis of transfer-deficient mutants of Flac in $E$. coli. Journal of Bacteriology 110, 831-842.

Achtman, M., Kennedy, N., Helmuth, R., Morelli, G., Beutin, L. \& Thompson, R. (1979). Cell-cell interactions in conjugating $E$. coli: conjugation proteins and the mating cycle. In Microbial Drug Resistance, vol. 2, pp. 157-168. Edited by $\mathrm{S}$. Mitsuhashi. Baltimore, London \& Tokyo: University Park Press.

Brinton, C. C. (1971). The properties of sex pili, the viral nature of conjugal genetic transfer systems, and some possible approaches to the control of bacterial drug resistance. Critical Reviews of Microbiology 1, 105-160.

Caro, L. G. \& Schnös, M. (1966). The attachment of the male-specific bacteriophage $f 1$ to sensitive strains of E. coli. Proceedings of the National Academy of Sciences of the United States of America 56, 126-132.

Crawford, E. M. \& Gesteland, R. F. (1964). The adsorption of bacteriophage R17. Virology 22, 165-167.

Date, T., Inuzuka, M. \& Tomoeda, M. (1977). Purification and characterization of $F$ pili from E. coli. Biochemistry 16, 5579-5585.

Finnegan, D. J. \& Willetts, N. S. (1971). Two classes of Flac mutants insensitive to transfer inhibition by an F-like R factor. Molecular and General Genetics 111, 256-264.

Folkhard, W., LeOnard, K. R., Malsey, S., Marvin, D. A., Dubochet, J., Engel, A., Achtman, M. \& Helmuth, R. (1979). X-ray diffraction and electron microscope studies on the structure of bacterial F pili. Journal of Molecular Biology 130, 145-160.

Gasson, M. J. \& Willetts, N. S. (1977). Further characterisation of the $F$ fertility inhibition systems of 'unusual' Fin ${ }^{+}$plasmids. Journal of Bacteriology 131, 413-420.

Helmuth, R. \& Achtman, M. (1975). Operon structure of DNA transfer cistrons on the F sex factor. Nature, London 257, 652-656.

Helmuth, R. \& Achtman, M. (1978). Cell-cell interactions in conjugating $E$. coli: purification of $F$ pili with biological activity. Proceedings of the National Academy of Sciences of the United States of America 75, 1237-1241.
JACOBSon, A. (1972). Role of F pili in the penetration of bacteriophage f1. Journal of Virology 10, 835843.

Kingsman, A. \& Willetts, N. (1978). The requirements for conjugal DNA synthesis in the donor strain during Flac transfer. Journal of Molecular Biology 122, 287-300.

Lawn, A. M., Meynell, E. \& Cooke, M. (1971). Mixed infections with bacterial sex factors: sex pili of pure and mixed phenotype. Annales de l'Institut Pasteur 120, 3-8.

MARVIN, D. \& HoHn, B. (1969). Filamentous bacterial viruses. Bacteriological Reviews 33, 172-209.

Miki, T., Horiuchi, T. \& Willetts, N. S. (1978). Identification and characterisation of four new tra cistrons on the $E$. coli sex factor F. Plasmid 1, 316-323.

Minkley, E. G., Polen, S., Brinton, C. C. \& IPPEN-IHLER, K. (1976). Identification of the structural gene for F-pilin. Journal of Molecular Biology 108, 111-121.

Novotny, C. P. \& Fives-Taylor, P. (1974). Retraction of F-pili. Journal of Bacteriology 117, 1306-1311.

O'Callaghan, R., Bradley, R. \& Paranchych, W. (1973). The effect of M13 phage infection upon the F pili of E. coli. Virology 54, 220-229.

Ohtsubo, E., Nishimura, Y. \& Hirota, Y. (1970). Transfer-defective mutants of sex factors in $E$. coli. I. Defective mutants and complementation analysis. Genetics 64, 173-188.

Orosz, L. \& Wooton, J. C. (1977). Isolation of four phenotypic classes of transfer-proficient, pilusspecific-bacteriophage-resistant mutants of an F-like plasmid of $E$. coli K12. Molecular and General Genetics 157, 223-230.

Ou, J. T. \& ANDERson, T. F. (1970). Role of pili in bacterial conjugation. Journal of Bacteriology 102, 648-654.

Paranchych, W. (1975). Attachment, ejection and penetration stages of the RNA phage infectious process. In The RNA Phages, pp. 85-111. Edited by N. Zinder. New York: Cold Spring Harbor Laboratory.

Tomoeda, N., Shuta, A. \& Inuzuka, M. (1972). Studies on sex pili: mutants of the sex factor $F$ in $E$. coli defective in bacteriophage-adsorbing function of $\mathrm{F}$ pili. Journal of Bacteriology 112, 1358-1363.

WILlETTS, N. S. (1971). The plasmid-specificity of two proteins required for conjugation in $E$. coli K12. Nature New Biology 230, 183-185.

Willetts, N. S. (1973). Characterisation of the F transfer cistrons, traL. Genetical Research 21, 205-213.

Willetts, N. S. \& Achtman, M. (1972). A genetic analysis of transfer by the $E$. coli sex factor F, using P1 transductional complementation. Journal of Bacteriology 110, 843-851. 